\title{
Financial Leverage of Faculty of Higher Educational Institutions in the Province of Capiz
}

\author{
Joesan D. Borres ${ }^{1}$ and Joseph G. Guevarra ${ }^{2}$ \\ ${ }^{1}$ Capiz State University, Capiz, Philippines \\ 2University of Negros Occidental-Recoletos, Bacolod City, Philippines
}

\begin{tabular}{l} 
Article history \\
Submitted: 23 October 2020 \\
Revised: 1 November 2020 \\
Accepted: 10 November 2020 \\
\hline Keywords \\
Business Management \\
Financial Leverage \\
Higher Educational Institution \\
Faculty \\
Descriptive-Correlational \\
Capiz
\end{tabular}

Accepted: 10 November 2020

\section{Keywords}

Business Management

ancial Leverage

Faculty

Capiz

\section{Article history}

Introduction. Faculty-entrepreneurs started their business using savings and personal money. Over time, with an insufficient amount of capital and to maximize business operation, faculty-entrepreneurs incur debt. Findings on financial literacy, financial capability, financial management, and faculty's financial well-being were very low and negative. So far, there is a dearth of studies that have been conducted on financial leverage, particularly on the faculty who are engaged in business. Financial leverage refers to the source of business capital used in the form of equity and debt. The paper explored the level of financial leverage in terms of equity and debt of faculty of higher educational institutions when they are taken as a whole and grouped according to age, sex, and gross monthly business income. Likewise, it determined the difference in the level of financial leverage in terms of equity and debt when teachers are grouped according to the demographics. Also, it explored the relationship between equity and debt. Likewise, it determined the result of financial leverage in their investment practices.

Methods. A descriptive, comparative, and correlational research design was used to assess the level of financial leverage in terms of equity and debt of faculty of Higher Educational Institutions in the province of Capiz during the school year 2019-2020. Using purposive sampling and total enumeration, 48 faculty-entrepreneurs participated in the study using a researcher-made questionnaire. Mean, standard deviation, frequency count, percentage distribution, Mann Whitney $U$ test, and Spearman rho rank correlation were used to analyze the data.

Results. The findings of the study show that the level of financial leverage in terms of equity and debt are both high. There is no significant difference in the level of financial leverage in terms of equity and debt when teachers are grouped according to the demographics. As to the relationship, there is a significant relationship between equity and debt. Also, use for a revolving fund, improvement of the facility, and business expansion are the investment practices using financial leverage.

Conclusion. Having full business ownership, faculty-entrepreneurs have the freedom to make decisions crucial to their business success. Business knowledge and skills are essential to strike the right balance of equity and debt. They have open access to financial institutions, and they take that financial advantage to leverage their business. They used the equity to finance its operating expenses with the intention that their business should be self-sufficient and sustainable. Debt is used for the improvement of the facility, business expansion, and other investments. The investment practices indicate faculty-entrepreneurs' commitment to improving their business to promote progress to the local economy by contributing to employment, growth, and social inclusion. Financial institutions come in because of the potentiality of their business. Also, they take calculated risks by maintaining a reasonable debt level since any financial obligations directly impact the cash flow, which could affect the liquidity, feasibility, viability, and sustainability of the business.

Practical Value of the Paper. The study significantly contributes to the few existing works of literature on the Financial Leverage of Higher Educational Institutions. Also, the findings of the study provided baseline information to faculty-entrepreneurs in formulating a financial plan for cash-flow management, investment management, tax planning, insurance assessment, retirement planning, and estate planning to address their needs and concerns. 


\section{References}

Ahmed, F., Awais, I., and Kashif, M. (2018). Financial leverage and firms' performance: empirical evidence from KSE100 index. Etikonomi: Jurnal Ekonomi, 17(1):45-56, doi: 10.15408/etk.v17i1.6102

Du, J. and Cai, Z-Q. (2020). The impact of venture capital on the growth of small- and medium-sized enterprises in Agriculture. Journal of Chemistry, doi:10.1155/2020/2328171

Ibrahim, M., and Ibrahim, A. (2015). The effect of SME's cost of capital on their financial performance in Nigeria. Journal of Finance and Accounting, 3:8-11, doi: 10.12691/jfa-3-1-2

McGuinness, G., and Hogan, T. (2016). Bank credit and trade credit: evidence from SMEs over the financial crisis. International Small Business Journal, 34:412-445, doi: 10.1177/0266242614558314

Quaye, I. and Sarbah, A. (2014). Assessing alternative financing sources for small and medium scale enterprises in Ghana: a case study of savings and loans companies (S \& LS) in the Greater Accra Region of Ghana. International Journal of Advancement in Research and Technology, 3(7), July 2014:123-136, ISSN 2278-7763

Wonglimpiyarat, J. (2015). Challenges of SMEs innovation and entrepreneurial financing. World Journal of Entrepreneurship, Management, and Sustainable Development, 11:295-311, doi: 10.1108/ WJEMSD-04-2015-0019

Xiang, D. and Worthington, A. (2015). Finance-seeking behavior and outcomes for small- and medium-sized enterprises. International Journal of Managerial Finance, 11(4):513-530, doi: 10.1108/IMF-01-2013-0005

Yacus, A.M., Esposito, S.E., and Yang, Y. (2019). The influence of funding approaches, growth expectations, and industry gender distribution on high-growth women entrepreneurs. Journal of Small Business Management, 57(1), doi: 10.1111/jsbm.12491

Yadollahi Farsi, .J. and Toghraee, M.T. (2014). Identification of the main challenges of small and medium-sized enterprises in exploiting innovative opportunities (case studies: Iran SMEs). J Glob Entrepr Res, 4(4), doi: $10.1186 / 2251-7316-2-4$

Yazdanfar, D. and Ohman, P. (2015). Debt financing and firm performance: an empirical study based on Swedish data. Journal of Risk Finance, 16:102-118, doi: 10.1108/JRF-06-2014-0085

\section{Correspondence:}

Joesan D. Borres [jdborres@capsu.edu.ph]

https://orcid.org/0000-0002-8942-9676 